\title{
THE MESOSTIGMATID MITE (ACARI, MESOSTIGMATA) COMMUNITY IN CANOPIES OF SITKA SPRUCE IN IRELAND AND A COMPARISON WITH GROUND MOSS HABITATS
}

\author{
J. Arroyo ${ }^{1}$, M. L. Moraza ${ }^{2} \&$ T. Bolger ${ }^{1}$
}

\section{SUMMARY}

J. Arroyo, M. L. Moraza \& T. Bolger. 2010. The Mesostigmatid mite (Acari, Mesostigmata) community in canopies of Sitka spruce in Ireland and a comparison with ground moss habitats. Graellsia, 66(1): 29-37.

The main aim of this study was to examine the communities of mesostigmatid mites occurring in Irish Sitka spruce (Picea sitchensis) canopies or inhabiting moss, either in the canopy or on the soil surface, and to discover whether a characteristic assemblage of species occurs in particular habitat patches (ground vs. aerial). Twenty two species of Mesostigmata were recorded, of which five occurred exclusively in arboreal microhabitats. All three species of Zerconidae collected were unique to the canopy and moss mats on the tree branches. Trachytes aegrota (C.L. Koch, 1841) was recorded for the first time in Ireland and some comments about its distribution are made. Multivariate analysis indicated that the arboreal mesostigmatid community is not just a subset of the assemblage occurring in moss on soil or trunks and that it appears to be more homogeneous than those occurring on the soil surface.

Key words: Acari; Mesostigmata; canopy; arboreal mites; Sitka spruce; Ireland.

\section{RESUMEN}

J. Arroyo, M. L. Moraza \& T. Bolger. 2010. La comunidad de ácaros Mesostigmata (Acari, Mesostigmata) en el dosel arbóreo de bosques de pícea en Irlanda en comparación con la presente en hábitats muscícolas edáficos. Graellsia, 66(1): 29-37 (en inglés).

El objetivo principal de este trabajo fue estudiar en Irlanda las comunidades de ácaros Mesostigmata del dosel arbóreo de bosques de Picea sitchensis y en el musgo desarrollado tanto en zonas aéreas como en la superficie edáfica, con el fin de determinar si la estructura y composición de éstas comunidades variaba entre los hábitats diferenciales (edáficos vs. aéreos). Se obtuvieron 22 especies de ácaros Mesostigmata, de las cuales 5 aparecieron solamente en micro-hábitats arbóreos. Las especies de la familia Zerconidae recogidas en este estudio se encontraron exclusivamente en ramas y musgos desarrollados en el dosel. Trachytes aegrota (C.L. Koch, 1841), es citado por primera vez para Irlanda. Se ofrecen asimismo comentarios sobre la distribución de esta especie. El análisis multivariante de los resultados indicó que las poblaciones arbóreas de ácaros Mesostigmata no son un mero

School of Biology and Environmental Science, Science Centre West, University College Dublin, .Dublin 4, Ireland. E-mail: juah2@yahoo.es \& tom.bolger@ucd.ie

2 Departamento de Zoología y Ecología, Facultad de Ciencias, Universidad de Navarra, C/ Irunlarrea s/n, Pamplona 31080 (Navarra), Spain. E-mail: mlmoraza@unav.es 
subconjunto estructural sino que forman una comunidad diferencial respecto a las presentes en hábitats muscícolas del tronco o del medio edáfico, y son más homogéneas que las existentes en la superficie del suelo.

Palabras clave: Acaros; Mesostigmata; dosel; ácaros arbóreos; Picea; Irlanda.

\section{Introduction}

Sitka spruce -Picea sitchensis (Bong.) Carr. (1832)-, a species native to North America, has been used widely for afforestation purposes in Ireland. It is chosen because it is a productive canopy species (Forest Service, 2000).

Although forest is the climax vegetation for most of Ireland, due to deforestation, only approximately $10 \%$ of the land is currently forested and more than $90 \%$ of the forests are plantations of exotic trees such as the aforementioned Sitka spruce (Fahy \& Foley, 2002).

Little is known of the biota inhabiting these plantations (Bolger, 2002) and this is especially the case for invertebrate fauna (Fahy \& Gormally, 1998). Recent research carried out by our team in these forests has increased our knowledge of the composition of the mite assemblages in these habitats (Arroyo \& Bolger, 2007; Moraza et al., 2009; Arroyo et al., 2009). Oribatid mites show high abundance and diversity in canopies (BehanPelletier \& Walter, 2000) and are the mites most studied in these ecological habitats. However, mesostigmatid mites also occur in canopies and their assemblages have been researched in this study. The importance of researching in these habitats is highlighted by the fact that forest canopies support diverse arthropod assemblages, which are largely distinct from those on the forest floor (e.g. for mites Walter \& Bellan-Pelletier, 1999). Indeed, Winchester (1997) points out that the distinct assemblage of oribatid mites inhabiting the canopy of coniferous trees in Western North America has been used as one of arguments for the conservation of these old-growth forests

The main goals of the current study were:

- To determine the species composition of the mesostigmatid fauna in Irish Sitka spruce stands.

- To study the community assemblages of Mesostigmata mites in several microhabitats within Sitka spruce stands.

- To test whether there are distinct assemblages in the microhabitats sampled.

\section{Materials and Methods}

The sampling was carried out in December 2005 and 2006 in two different aged Sitka spruce plantations located in Co Laois, Ireland (Fig. 1):

- Baunreagh: stand planted in 1925. Elevation: $360 \mathrm{~m}$. Coordinates: $\sim 53^{\circ} 07^{\prime} \mathrm{N}, 7^{\circ} 34^{\prime} \mathrm{W}$

- Dooary: stand planted in 1990. Elevation: 200 m. Coordinates: $\sim 52^{\circ} 57^{\prime} \mathrm{N}, 7^{\circ} 15^{\prime} \mathrm{W}$

Further details can be found in Arroyo et al. (2009) and Black et al. (2007).

In Baunreagh, samples were collected from five randomly selected trees by climbers and, in Dooary, from three trees by the senior author, using a portable climbing tower. The sampling followed protocols developed by Finnamore et al. (2004) and BehanPelletier (com. pers., 2005). Five sections of one branch approximately $25 \mathrm{~cm}$ in length and with a similar diameter were collected in each tree from the top of the living crown $(\sim 40 \mathrm{~m}$ Baunreagh / $11 \mathrm{~m}$ Dooary), mid crown $(\sim 38 \mathrm{~m} / 10 \mathrm{~m})$ and at the bottom of the living canopy $(\sim 36 \mathrm{~m} / 9 \mathrm{~m})$. The main epiphytic moss cover was removed and the branches and twigs were bathed in a dilute solution of $\mathrm{NaOH}$ for 48 hours. The liquid was then filtered $(85 \mu$ mesh size) and the animals collected. The subsamples collected from each branch were combined for each height within an individual tree to make a composite sample. This makes five replicate trees and three heights giving a total of 15 canopy samples coded as CT B for the Baunreagh site and three replicate trees and three heights accounting for a total of 9 canopy samples coded as CT D for the Dooary stand.

In the Baunreagh forest (oldest site), the moss cover developed in the branches was made up mainly of Hypnum cupressiforme Hedwig, 1801 at the three heights. This epiphytic material was carefully recovered and the mite fauna occurring in it extracted using Berlese funnels (Coineau, 1974). In this microhabitat we had five trees and 3 heights accounting for a total of 15 bryophytes samples coded as CM B. The samples were variable in size and were taken from the junction of the trunk and the selected 


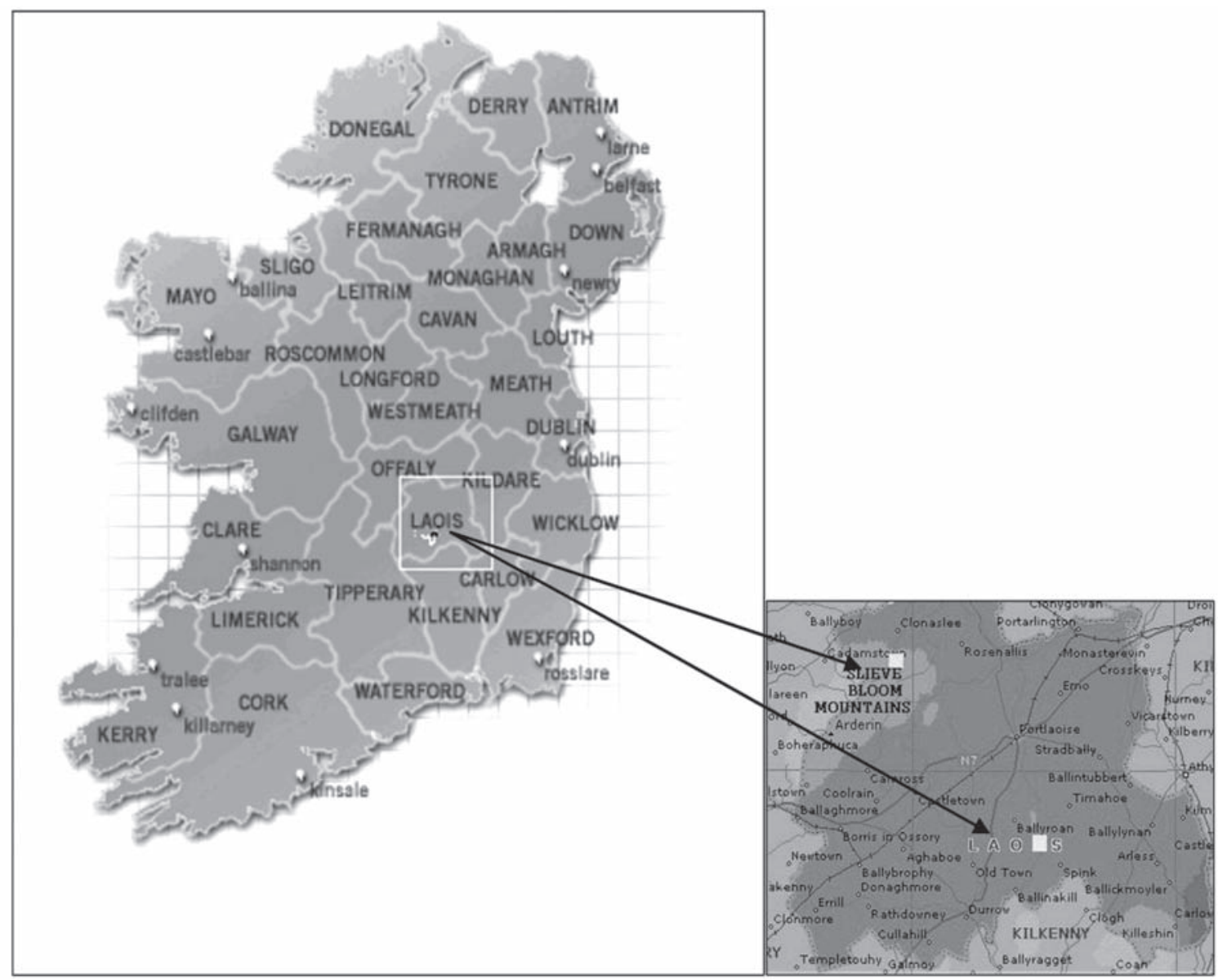

Fig. 1.- Location of the Baunreagh and Dooary Sitka Spruce stands in Co Laois, Ireland.

Fig. 1.- Localización en el condado de Laois (Irlanda) de las plantaciones de Baunreagh y Dooary.

branches, at the same heights as the samples of the canopy fauna. The forest growing in Dooary did not have enough epiphytic cover to allow sampling.

In these two arboreal microhabitats all samples for each height class were combined and coded using $\mathrm{L} / \mathrm{M} / \mathrm{U}$ extension for the lower, middle and upper levels. These pooled samples for habitat and plantation were used for the multivariate analysis.

Samples of moss were also taken from other microhabitats in both plantations and the biota was extracted using a Berlese funnel over a period of two weeks. Moss mats on the floor were collected using 16 random quadrats $(10 \times 10)$ later combined to give two samples for each stand. Baunreagh samples were coded as SM B. The moss community was mainly Sphagnum sp, Thamnobryum alopecurum (Hedw.),
Polytrichum commune Hedw., with Rytidiadelphus loreus Green and Klinka, 1994 being less abundant. The Dooary soil moss samples were coded as SM D.

In the Baunreagh stand, 8 moss quadrats of $10 \mathrm{x}$ $10 \mathrm{~cm}$ were also collected along the upper bark surface of two fallen stems and combined and coded as FTM B. The epicorticolous assemblage was dominated by $H$. cupressiforme.

Finally, at Dooary, samples of the sparse moss mats on the bases of the trunk $(0-25 \mathrm{~cm})$ were collected from two trees (coded as TM D).

All adult mesostigmatid mites were slide mounted in Hoyer's liquid and the more sclerotized animals cleared using Nesbitt's and posteriorly identified to species level using the keys of Karg (1993), Hyatt \& Emberson (1988) and Evans \& Till (1979). 


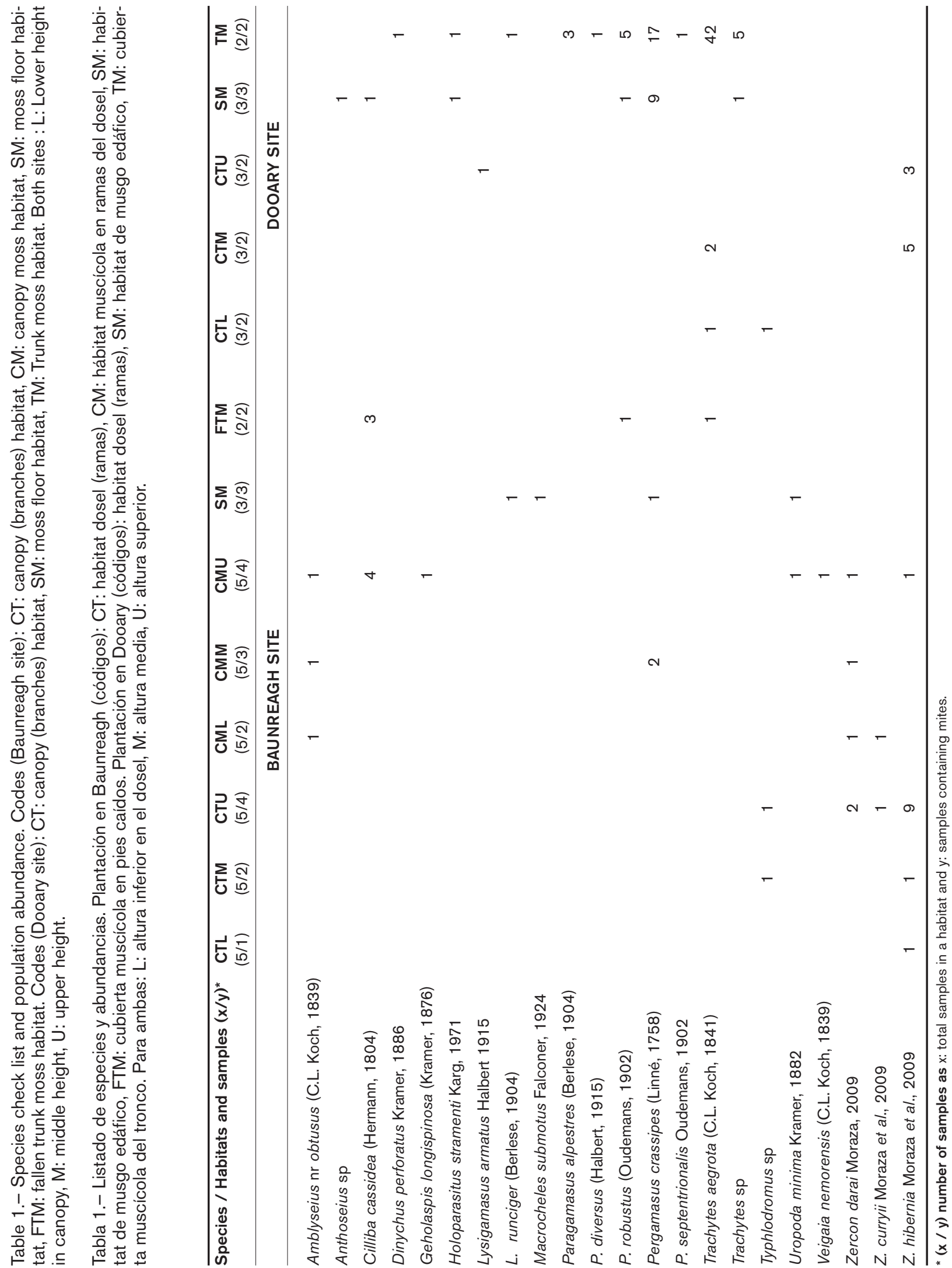




\section{Data Analyses}

A multivariate analysis was carried out to explore the relationships between the different habitats and the mite assemblages inhabiting them. The ordination algorithm used was a Detrented Correspondence Analysis (DCA) using CANOCO community ordination program (Ter Braak \& Šmilauer, 2002). The DCA was chosen in order to allow representation of rare species and all Mesostigmata taxa, even rare ones, were included in the analysis. It was also chosen because there was a high proportion of zeroes in the data matrix. In a second approach a cluster classification was obtained through TWINSPAN analysis. TWINSPAN is a divisive, hierarchical classification (Hill, 1994) which was carried out to summarise community composition. Samples containing no mites were not used in these analyses.

\section{Results}

A total of 146 adult mesostigmatid mites were collected (see Table 1) comprising up to 22 species. One of these is a first record for Ireland of Trachytes aegrota (C.L. Koch, 1841).

Of the twenty two species recorded, five were found exclusively in arboreal microhabitats. All three species of Zercon collected occurred only in the canopy microhabitats and were new to science, being recently described by Moraza et al. (2009).

The DCA (Length of gradient for first axis: 2.88) ordination showed clear clusters related to habitats (Fig. 2) and this was especially evident for canopy microhabitat for both forests. DCA was primarily selected as an indirect ordination technique and the ecological results displayed in the analysis were subsequently confirmed by the TWINSPAN classification (Table 2) which corroborated that the assemblages were divided into two obvious groupings, those from the canopies of both forests and those from the other microhabitats. There is a distinct grouping of species associated with the canopies which includes Zercon hibernia Moraza, Arroyo \& Bolger 2009, Zercon darai Moraza, 2009, Typhlodromus sp and Zercon curryii Moraza, Arroyo \& Bolger 2009. This group also includes Lysigamasus armatus Halbert, 1915 while Trachytes aegrota, although it was found in the canopies, appears mainly in other samples.

The differences between assemblages of mesostigmatid mites in the different microhabitats showed that communities in canopies are not a subset of ground populations but rather habitats colonized by characteristic fauna including typical or strictly arboreal genera as well as some wandering taxa. This ecological fact is similar for oribatid mites (Proctor et al., 2002).

\section{Discussion}

The abundance of mites recovered is similar to what others have found for this group for temperate coniferous soils (Čoja \& Bruckner, 2003; Huhta, 1996) but is much lower for arboreal samples previously recorded in canopies of Thuja (Lindo \& Winchester, 2006). In subtropical rain forest from Eastern Australia a relatively species-poor collection of mesostigmatid mites was also found on the surface of tree trunks (Beaulieu et al., 2006). In fact, the diversity and abundances shows that the mesostigmatid mites are similarly poor in the canopies of Irish Sitka spruce as were the oribatids (Arroyo et al., 2009).

The faunistic records collected were a bit surprising. Although species from the families Phytoseiidae and Uropodidae, commonly found on tree trunks and large stems, especially associated with growths of epicorticolous bryophytes and lichens, were obtained in our study, individuals belonging to the families Ologamasidae and Ascidae, usually collected in these habitats (Andre, 1986; Emmanouel \& Panou, 1991), were not collected. The presence in the samples of Thyplodromus, Amblyseius and Anthoseius was expected because Phytoseiidae mites are widely distributed in most terrestrial ecosystems, living in foliage or on the bark of trees and bushes, while some species are common in litter and soil habitats (Evans et al., 1985).

Cilliba cassidea and Trachytes aegrota have been collected in small numbers in aerial habitat.

The lack of more species belonging to the genus Veigaia, apart from V. nemorensis (C.L. Koch, 1839) from epiphytic moss, was not surprising because although four species had previously been found in the soil at the Dooary site, none were found in moss (Arroyo \& Bolger, 2007).

Several species of Parasitidae and Macrochelidae were found in the moss on the bases of the tree trunks and on the soil surface. For example, Pergamasus crassipes (Linné, 1758), a common predatory mite, was collected in moss on the soil sur- 
Table 2.- TWINSPAN classification analysis. The habitats researched are coded as in Table 1 and 2 with and added B (Baunreagh) or D (Dooary) for the site.

Tabla 2.- Análisis de clasificación (TWINSPAN). Los hábitats son codificados como en las Tablas 1 y 2 con cola añadida por sitio de estudio: B (Baunreagh), D (Dooary).

\begin{tabular}{|c|c|c|c|c|c|c|c|c|c|c|c|c|c|c|}
\hline & $\begin{array}{c}\text { FTM } \\
\text { B }\end{array}$ & $\begin{array}{c}\text { TM } \\
\text { D }\end{array}$ & $\begin{array}{c}\text { CMM } \\
\text { B }\end{array}$ & $\begin{array}{c}\text { CMU } \\
\text { B }\end{array}$ & $\begin{array}{c}\text { SM } \\
\text { B }\end{array}$ & $\begin{array}{c}\text { SM } \\
D\end{array}$ & $\begin{array}{c}\text { CTM } \\
\text { B }\end{array}$ & $\begin{array}{c}\text { CTL } \\
\text { D }\end{array}$ & $\begin{array}{c}\text { CTL } \\
\text { B }\end{array}$ & $\begin{array}{c}\text { CTU } \\
\text { B }\end{array}$ & $\begin{array}{c}\text { CTM } \\
\text { D }\end{array}$ & $\begin{array}{c}\text { CTU } \\
\text { D }\end{array}$ & $\begin{array}{c}\text { CML } \\
\text { B }\end{array}$ & \\
\hline P. alpestris & . & 1 & . & . & . & . & . & . & . & . & & . & . & 0000 \\
\hline P. diversus & . & 3 & . & . & . & . & . & . & . & . & . & . & . & 0000 \\
\hline P. robustus & 1 & 4 & . & . & . & 1 & . & . & . & . & . & . & . & 0000 \\
\hline$P$.septentrionalis & . & 5 & . & . & . & . & . & . & . & . & . & . & . & 0000 \\
\hline M. submotus & & 2 & . & . & 1 & . & . & . & . & . & . & . & . & 0001 \\
\hline C. cassidea & 2 & 1 & . & 2 & . & 1 & . & . & . & . & . & . & . & 0010 \\
\hline G. longispinosus & . & 1 & . & 1 & . & . & . & . & . & . & . & . & . & 0010 \\
\hline Anthoseius sp & . & . & . & . & . & 1 & . & . & . & . & . & . & . & 0011 \\
\hline H. stramenti & . & . & . & . & . & 1 & . & . & . & . & . & . & . & 0011 \\
\hline L. runcinger & . & . & 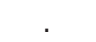 & . & 1 & & . & . & . & . & . & . & . & 0011 \\
\hline P. crassipes & . & 1 & 2 & . & 1 & 3 & . & . & . & . & . & . & . & 0011 \\
\hline Trachytes sp & . & . & . & & . & 1 & . & . & . & . & . & . & . & 0011 \\
\hline U. minima & . & . & . & 1 & 1 & . & . & . & . & . & . & . & . & 0011 \\
\hline V. nemorensis & . & . & . & 1 & . & . & . & . & . & . & . & . & . & 0011 \\
\hline A. $\mathrm{nr}$ obtusus & 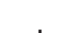 & . & 1 & 1 & . & . & . & . & . & . & & . & 1 & 01 \\
\hline T. aegrota & 1 & 3 & . & . & . & . & . & 1 & . & . & 2 & & . & 10 \\
\hline L. armatus & . & 1 & . & & . & . & . & . & . & . & . & 1 & . & 110 \\
\hline Z. darai & . & . & 1 & 1 & . & . & - & . & . & 2 & . & . & 1 & 110 \\
\hline Typhlodromus sp & . & . & . & . & . & . & 1 & 1 & . & 1 & . & . & . & 111 \\
\hline Z. curryii & . & . & . & & . & . & & . & . & 1 & & & 1 & 111 \\
\hline \multirow[t]{4}{*}{ Z. hibernia } & & 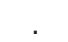 & & 1 & 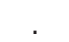 & & 1 & . & 1 & 3 & 3 & 2 & . & 111 \\
\hline & 0 & 0 & 0 & 0 & 0 & 0 & 1 & 1 & 1 & 1 & 1 & 1 & 1 & \\
\hline & 0 & 0 & 1 & 1 & 1 & 1 & 0 & 0 & 0 & 0 & 0 & 0 & 1 & \\
\hline & & & & & & & 0 & 0 & 1 & 1 & 1 & 1 & & \\
\hline
\end{tabular}

face and in moss mats developed on stems from Baunreagh. This fact corroborates the wandering behaviour of this species which has been recorded in other coniferous forests such as yews in Great Britain (Thomas \& Polwart, 2003).

We offer here the first records of Trachytes aegrota for a geographical concrete location within Ireland. Although the island was included in the European distribution map for the species by Błoszyk et al. (2003), and this is considered by Wisniewski \& Hirschmann (1993) to occur in all of Europe, no specific bibliographic references were offered for these records and the authors are not aware of any. No reference to this taxon is made in the previous works on Ireland (O'Connell, 1994) or in the Acarina check list for the country (Luxton, 1998) or in the reference specimen collection at UCD. T. aegrota is commonly found in Sitka habitats as well as other forestry with its abundance declining from north Europe to Mediterranean areas. In Ireland two species of this genus, T. minima and $T$. oudemansi have been recorded previously and sensu Mašán (2003) most morphological characters of $T$. oudemansi are almost identical with those of $T$. aegrota, which only lacks the broad lateral margins of the vertex in the latter. Mašán's belief that $T$. oudemnasi is synonymous with $T$. aegrota may be justified, but we keep our criteria of considering each a different species.

The three species of Zercon collected in this study were recovered exclusively in arboreal habitats and found to be new to science. Together with more type material of these species recovered in canopies researched for our team from Quercus petreae and Taxus baccata woods, the new Zercon species were described (Moraza et al., 2009) suggesting the need for deeper research on gamasids inhabiting these ecosystems. 


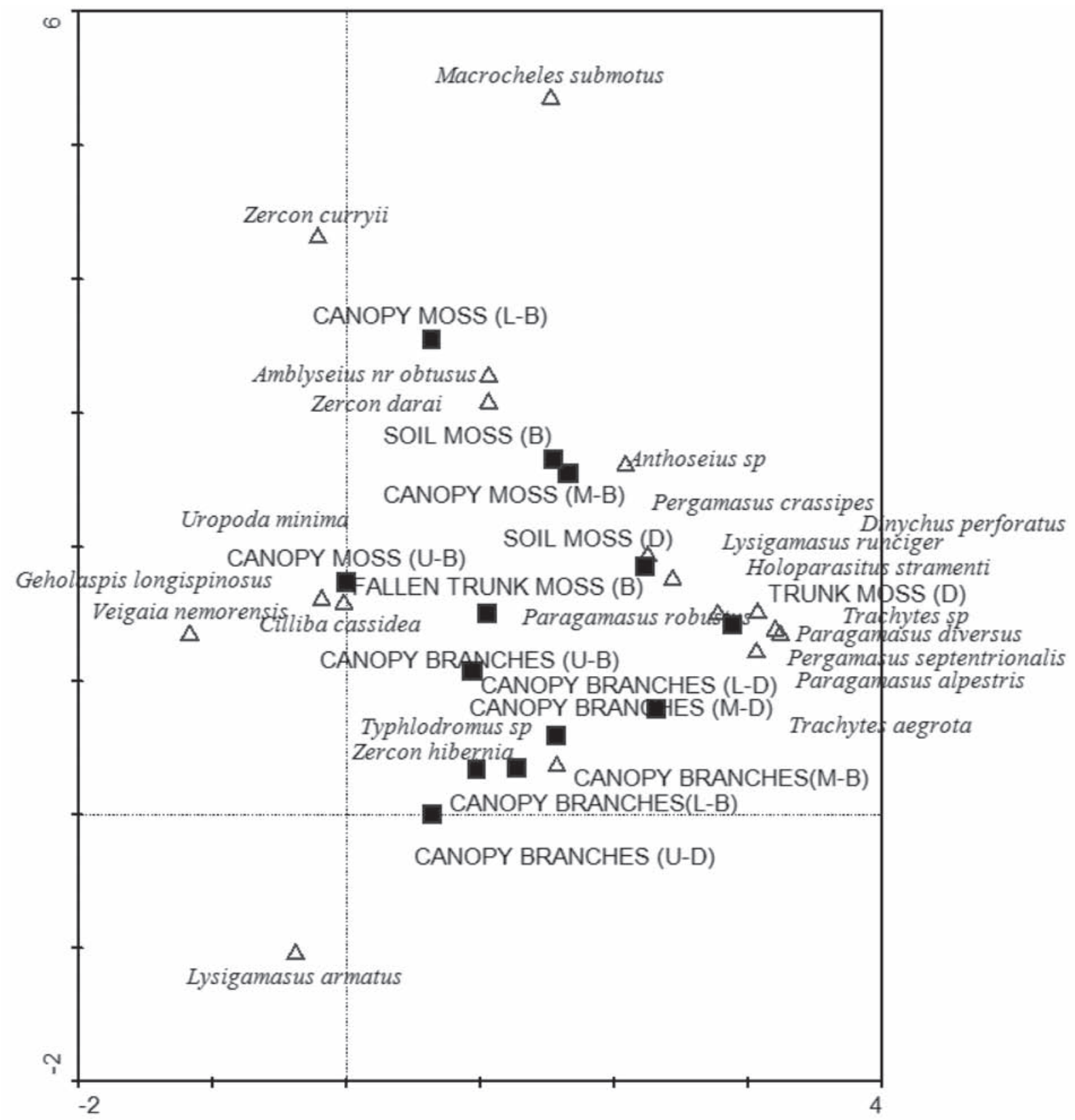

Fig. 2.- Detrented Correspondence Analysis (DCA) biplot. The habitats are displayed in the graph adding a tail: $B$ (Baunreagh) or $\mathrm{D}$ (Dooary) for the site and L, M and $U$ for lower, middle and upper height.

Fig. 2.- Diagrama de ordenación basado en el Análisis de Correspondencias sin tendencias (DCA). Los hábitats se muestran en la figura con cola añadida por sitio de estudio: B (Baunreagh), D (Dooary) y por altura: L, M y U codificando inferior, media y superior. 
The abundances differed strongly between microhabitats. Beaulieu et al. (2006), in their research on Australian rainforest, indicate that the mesostigmatid mite fauna (Uropodina excluded) of tree trunks was mainly composed by a mixed set dominated by suspended soil inhabitants and 'generalist' species, suggesting that tree trunks represent a 'highway' for most Mesostigmata, while others use it as a permanent habitat. In our study the faunistics of the tree trunk moss collected suggest a more differentiated assemblage despite the presence of abundant and common species such as $C$. cassidea and $P$. crassipes which also occurred in the other microhabitats sampled.

The variation found between assemblages of mesostigmatid mites in the canopies in comparison with floor habitats in combination with the data already in the literature for other mites and microarthropods suggests the importance of continued study of the contributions of these assemblages to ecosystem functions because, as Lindo \& Winchester (2007) remark, the decomposition process in canopy ecosystems is expected to differ from that of forest floor ecosystems due to biotic factors such as differences in diversity of oribatid mite and other microarthropod assemblages, and abiotic parameters that operate at microscale levels.

Finally as expected, based on previous work carried out by our team, there were low richness and abundance of mites in the canopies (branches) of Irish Sitka spruce, with increased diversity in the epiphytic mat microhabitats, but even in these niches, the richness and diversity is depauparate when compared with the fauna of native coniferous forest in North America, and specially in Sitka spruce, which is native to that geographical area.

\section{Acknowledgments}

The authors wish to thank the Spanish Science Ministry (MEC) and the FUNCTIONALBIO project funded by COFORD (The National Council for Forest Research and Development in Ireland) for supporting Dr Julio Arroyo with post doctoral grants. Also thanks are due to Dr Kevin Black for his help with the fieldwork. The authors are also grateful to the referees and to Pepe Fernández for their help and advice.

\section{References}

André, H.M., 1986. Notes on the ecology of corticolous epiphyte dwellers. 4. Actinedida (especially Tydeidae) and Gamasida (especially Phytoseiidae). Acarologia, 26: $107-15$.
Arroyo, J. \& Bolger, T., 2007. Oribatid (Acari: Oribatida) and gamasid (Acari: Gamasida) mite communities in an Irish Sitka spruce Picea sitchensis (Bong.) Carr. stand with three first records for Ireland. Irish Naturalists Journal, 28(11): 452-458.

Arroyo, J., Neville, P. \& Bolger, T., 2009. Mites occurring in Sitka Spruce growing in Ireland. In: M. W. Sabelis \& J. Bruin (eds.). Trends in Acarology. Springer. Amsterdam: 105-109.

Balogh, J. \& Mahunka, S., 1983. Primitive Oribatids of the Palaeartic region. In: J. Balogh \& S. Mahunka (eds.). The soil mites of the world, vol. I. Elsevier. Amsterdam-Oxford-New York: 1-372 pp.

Beaulieu, F., Walter D. E., Proctor H. C., Kitching R. L. \& Menzel, F., 2006. Mesostigmatid mites (Acari: Mesostigmata) on rainforest tree trunks: arboreal specialists, but substrate generalists? Experimental and Applied Acarology, 39: 25-40.

Behan-Pelletier, V. M. \& Walter, D. E., 2000. Biodiversity of Oribatid mites (Acari: Oribatida) in tree canopies and litter. In: D. C. Coleman \& P. F. Hendrix (eds.). Invertebrates as Webmaster in Ecosystems. $\mathrm{CAB}$ International. Wallingford \& New York: 187-202.

Black, K., Bolger, T., Davis, P., Nieuwinhus, M., Reidy, B., Saiz, G., Tobin, B. \& Osborne, B., 2007. Inventory and eddy covariance-based estimates of annual carbon sequestration in a Sitka spruce (Picea sitchensis (Bong.) Carr. forest ecosystem. European Journal of Forest Research, 126: 167-178.

Błoszyk, J., Bajaczyk, R., Markowicz, M. \& Gulvik, M., 2003. Geographical and ecological variability of mites of the suborder Uropodina (Acari: Mesostigmata) in Europe. Biological Letters, 40(1): 15-35.

Bolger, T., 2002. Examining the effects of land use, particularly afforestation, on biodiversity. In: L. MacLennan (ed.). Proceedings of Coford seminar: Opportunities for Biodiversity enhancement in plantation forest. COFORD. Cork: 23-38.

Coineau, N., 1974. Introduction à l'étude des microarthropodes du sol et ses annexes. Doin. Paris. 119 pp.

Čoja, T. \& Bruckner, A., 2003. Soil microhabitat diversity of a temperate Norway spruce (Picea abies) forest does not influence the community composition of gamasid mites (Gamasida, Acari). European Journal of Soil Biology, 39: 79-84.

Emmanouel, N. G. \& Panou, H., 1991. A study on mites associated with bark and twigs of various trees in Attica (Greece). In: F. Dusbábek \& V. Bukva (eds.). Modern Acarology, vol 1 (Proceedings of the $8^{\text {th }}$ International Congress of Acarology, Ceske Budejovice). SPB Academic Publishing. The Hague: 523-532.

Evans, G. O., Griffiths, D., MacFarlane, D., Murphy, P. W. \& Till, W. M., 1985. The Acari. A practical manual, vol. 1. Morphology and classification. University of Notthingham, School of Agricultural. Sutton Bonington. $256 \mathrm{pp}$. 
Evans, G. O. \& Till, W. M., 1979. Mesostigmatic mites of Britain and Ireland (Chelicerata: Acari-Parasitiformes): An introduction to their external morphology and classification. Transactions of the Zoological Society of London, 35: 139-270.

Fahy, O. \& Foley, N., 2002. Biodiversity opportunities in plantations managed for wood supply. In: L. MacLennan (ed.). Proceedings of Coford seminar: Opportunities for Biodiversity enhancement in plantation forest. COFORD. Cork: 1-5.

Fahy, O. \& Gormally, M., 1998. A comparison of plant and carabid communities in an Irish oak woodland with a nearby conifer plantation and a clear felled site. Forest Ecology and Management, 110: 263-273.

Finnamore, A. T., Winchester, N. N. \& Behan-Pelletier, V. M., 2004. Protocols for measuring biodiversity: Arthropod monitoring in terrestrial ecosystems. In: EnvironmentCanada (http://www.emanrese.ca/eman/ ecotools/protocols/terrestrial/arthropods/intro).

Forest Service, 2000. Forest Biodiversity Guides. Forest Service Department of the Marine and Natural Resources. Dublin.

Hill, M. O., 1994. DECORANA and TWINSPAN, for Ordination and Classification of Multivariate Species Data: A New Edition, Together with Supporting Programs, in FORTRAN 77. Institute of Terrestrial Ecology. Huntingdon.

Huhta, V., 1996. Community of Mesostigmata (Acari) in experimental habitat patches of forest floor. European Journal of Soil Biology, 32: 99-105.

Hyatt, K. H. \& Emberson, R. M., 1988. A review of the Macrochelidae (Acari: Mesostigmata) of the British Isles. Bulletin of the British Museum (Natural History) Zoology, 54(2): 63-125.

Karasawa, S. \& Hijii, N., 2004. Morphological modifications among oribatid mites (Acari: Oribatida) in relation to habitat differentiation in mangrove forests. Pedobiologia, 48: 383-394.

Karg, W., 1993. Acari (Acarina), Milben Parasitiformes (Anactinochaeta), Cohors Gamasina Leach, Raubmilben. Die Tierwelt Deutschlands, 59: 1- 523.

Koponen, S., Rinne, V. \& Clayhills, T., 1997. Arthropods in oak branches in Finland, collected by a new trap type. Entomologica Fennica, 8(33): 177-183.

Lindo, Z. \& Winchester, N. N., 2006. A comparison of microarthropod assemblages with emphasis on oribatid mites in canopy suspended soils and forest floors associated with ancient western redcedar trees. Pedobiologia, 50: 31-41.

Lindo, Z. \& Winchester, N. N. 2007. Oribatid mite communities and foliar litter decomposition in canopy suspended soils and forest floor habitats of western redcedar forests, Vancouver Island, Canada. Soil Biology and Biochemistry, 39: 2957-2966.
Luxton, M., 1998. The oribatid and Parasitiform mites of Ireland, with particular reference to the work of J.N. Halbert (1872-1948). Bulletin of the Irish Biogeographical Society, 22: 2-73.

Mašán, P., 2003. Identification key to Central European species of Trachytes (Acari: Uropodina) with redescriptions, ecology and distribution of Slovak species. European Journal of Entomology, 100: 435-448.

Moraza, M. L., Arroyo, J. \& Bolger T., 2009. Three new species of mites (Acari: Zerconidae) from canopy habitats in Irish forests. Zootaxa, 2019: 29 -39.

O'Connell, T., 1994. The microarthropod fauna associated with fungal fruiting bodies in woodland. A study of the role of habitat spatial and temporalcdiversity in determining assemblage structure. Unpublished Ph.D. Thesis. Department of Zoology, University College. Dublin. 260 pp.

Proctor, H. C., Montgomery, K. M., Rosen, K. E. \& Kitching, R. L., 2002. Are tree trunks habitats or highways? A comparison of oribatid mite assemblages from hooppine bark and litter. Australian Journal of Entomology, 41: 294-299.

Ter Braak, C. J. F. \& Šmilauer, P., 2002. CANOCO Reference Manual and CanoDraw for Windows User's guide: Software for Canonical Community Ordination (version 4.5). Microcomputer Power. Ithaca.

Thomas, P. A. \& Polwart, A., 2003. Taxus baccata L. Journal of Ecology, 91: 489-524.

Walter, D. E. \& Behan-Pelletier, V. M., 1999. Mites in forest canopies: filling the size distribution shorfall ? Annual Review of Entomology, 44: 1-19.

Winchester, N. N., 1997. Canopy arthropods of coastal Sitka spruce trees on Vancouver Island, British Columbia, Canada. In: N. E. Stork, J. Adis \& R. K. Didham (eds.). Canopy Arthropods. Chapman \& Hall. London: 151-168.

Winchester, N. N., Behan-Pelletier, V. M. \& Ring, R. A., 1999. Arboreal specificity, diversity and abundance of canopy-dwelling oribatid mites (Acari: Oribatida). Pedobiologia, 43: 391-400.

Wisniewski, J. \& Hirschmann, W., 1993. Katolog der Gangattungen, Untergattungen, Gruppen und Arten der Uropodiden der Erde (Taxonomie, Literatur, Grosse, Verbreitung, Vorkommen). Acarologie, 40: $1-220$.
Recibido, 22-XII-2009 Aceptado, 14-IV-2010 Publicado, 30-VI-2010 